\title{
Towards critical aspects of Confucianism ${ }^{1}$
}

\author{
Lubomír Dunaj
}

\begin{abstract}
This paper consists of two parts. The first deals with the issue of whether it is possible to coherently employ the term 'critical Confucian' in general, i.e. whether it is a paradox or oxymoron. It will be argued that Confucianism should not be identified with any particular ideology and, therefore, can be critical. This critical potential, in turn, can be developed by bringing it into dialogue with Critical Theory. As such, the second part indicates, in an introductory way, some possible overlaps between Confucianism and Critical Theory by comparing Heiner Roetz's and Axel Honneth's respective interpretations of these traditions.
\end{abstract}

Keywords: Chinese philosophy, Confucianism, Critical theory, Global ethics

\section{Introduction}

There are several reasons why Western social and political philosophers should begin to inquire into non-Western ethical, social and political thought. One of them is connected to the increase of global interactions in recent decades, which demand global solutions for a wide range of social and environmental problems. As a rising superpower, China arguably occupies the most important position among non-Western countries. Consequently, it is necessary to understand the most influential philosophical traditions of such an important 'global player', as well those of the so called Far East Asian civilizations - in order to arrive at a better grasp of the dynamics of the globalized world.

Another important reason why Western scholars should be interested in China is the fact that Chinese culture is one of the axial civilizations and its spiritual and philosophical heritage therefore belongs to the oldest in world history, alongside Greek (with its Near East's "progenitors") and Indian civilizations. ${ }^{2}$ Indeed, traditional Chinese philosophy offers many indigenous notions and ideas, which are still alive in Chinese social and political discourse and enjoy growing attention. As a result, they have to be included in the debate about global ethics if China is to be recognised as an equal partner in the discussion. ${ }^{3}$

Last but not least, it is worth noting the necessity of providing a critique of the Eurocentric interpretation of world philosophy and history, which one might argue is still present in Western philosophy today. Consequently, a critique of Eurocentrism, which can also be found in Critical Theory, ${ }^{4}$ provides a strong motivation for the study of Chinese philosophy and may provide a source for self-critique of western philosophy. Thus, as Heiner Roetz writes: "After the end of the cosmopolitism of the Enlightenment, Occidental uniqueness and superiority have become firm features of the Western self-understanding. Hegel's statement that 'the

\footnotetext{
${ }^{1}$ The key ideas of this paper were presented at the 'China-Workshop' (Thinking through Paradoxes. Between Critical Theory and Contemporary Chinese Philosophy), which took place in 2016 from July $8^{\text {th }}$ to $9^{\text {th }}$ at the Institute of Social Research at the Goethe University in Frankfurt am Main. I am very thankful to Fabian Heubel, Heiner Roetz, Johann, P. Arnason, Daniel Karanovic and Kurt C. Mertel for their inspiring comments.

${ }^{2}$ For the issue of the 'Axial Age debate' cf.: (Bellah \& Joas, 2012; Arnason, Eisenstadt \& Wittrock, 2005)

${ }^{3}$ For the global relevance of Chinese ethical thought cf.: (Shun \& Wong, 2004; Yu, Tao \& Ivanhoe, 2010)

${ }^{4}$ Regarding the unfamiliarity with China among critical theorists belonging to the tradition of the Frankfurt School, see, for instance, Fabian Heubel's study 'Transkulturelle Kritik und die Chinesische Moderne. Zwischen Frankfurter Schule und Neokonfuzianismus,' which begins with the question: "What does the Critical Theory knows about China, traditional Chinese Culture, or even about modern Chinese thought? Almost nothing [translation - L'.D., orig. in German]" (Heubel, 2009, p. 43).
} 
Oriental has to be excluded from the history of philosophy' and Leopold Ranke's echo that for understanding world history 'one cannot start from the peoples of eternal standstill' are two prominent examples for a conviction that became dominant in the historical disciplines. World philosophy and world history have been Occidental" (Roetz, 2012, p. 248). Western philosophers and social scientists simply cannot afford to adopt such uncritical perspectives in times of the accelerating globalization of culture, economy and politics. Hence, we can agree with Thomas A. Metzger, who concludes his analysis of the relevance of contemporary Chinese political theories, that "whether the Western theories make more sense than the Chinese is not a question one should prejudge" (Metzger, 2005, p 13). He explains that "contemporary Chinese political theories [...] not only constitute a distinctive way of thinking about how to improve political life," but "they may indeed include insights contemporary Western theories have neglected" (Metzger, 2005, p. 12). A similar attitude should also characterise contemporary Western philosophical approaches, as well as inquiries into other humanities especially if they have global pretensions.

The aim of this paper is twofold. First, one of the obstacles to the fruitful appropriation of Confucian philosophy for contemporary ethics has been its identification with a particular ideology, which has led to paradoxical readings of Chinese philosophical heritage. Hence, the first section will be devoted to resolving the paradox in order to make room for a 'critical' alternative or for what we might call a 'critical Confucian ethics'. Having cleared the path for such an ethics, in the second part of the paper it will be argued that both Confucianism and Critical Theory can benefit from mutual dialogue and indicate an important point of contact which might serve as a fruitful basis for such a dialogue, viz. the critique of liberalism and communitarianism captured by Axel Honneth's notion of 'social freedom'.

\section{Confucianism as a critical philosophy}

The point of departure for this paper is a paradox which I have encountered in the CzechSlovak "debate" between the sinologists Lukáš Zádrapa, the translator of Han Feizi into Czech (Chan-Fej-c', 2011; Chan-Fej-c', 2013) and Jaromír Vochala, the translator of the Analects of Confucius, Doctrine of the Mean and Great Learning into Czech (Vochala, 2009) about the contemporary relevance of Chinese philosophy. It is also important to mention the contribution of Marina Čarnogurská, the translator of Daodejing, Analects of Confucius and A Dream of Red Mansions into Slovak (Čarnogurská, 2009; 2012; Konfucius, 2002; Cchao Süečchin, 2001-2006) to this discussion who proposes that Daoist philosophy and its 'comprehensive' (and 'total') grasp of reality is the basic precondition for the solution of (almost) all of our political, social, environmental and other problems. These sinologists are directly connected to the Prague School of Sinology, which was founded by Jaroslav Prǔšek (1906-1980), one of the greatest world Sinologists of his time.

All of the aforementioned sinologists agree on the main problems of our times, especially on the neoliberal character of globalisation and its negative impacts on social and human affairs in contemporary societies. However, they all adopt different positions regarding the role Chinese philosophy plays or should play in a discussion about global ethics.

Zádrapa, for example, argues that Chinese philosophy can be employed to justify neoliberal policies and technocratic governing (Zádrapa, 2011, p. 19). Paradoxically, by employing almost the same critique of global capitalism, Vochala argues that Chinese philosophy could provide guidance in correcting and improving current international

\footnotetext{
${ }^{5}$ In fact, it was not a real dispute, but rather critical comments and remarks, which were offered by the mentioned sinologists to each other.
} 
problems. He emphasizes in particular the potential of the Great Learning ${ }^{6}$ which, according to him, indicates a path to becoming a person who cares for humankind as a whole (Vochala, 2009, p. 379), as opposed to the atomised individual of neoliberal ideology.

My interest in Chinese philosophy as a Western philosopher is to understand the role and place of China in an increasingly globalized world. The main problem for me as a nonsinologist with regard to aforementioned 'Czechoslovak' sinologists is the question of how these scholars can offer such divergent and paradoxical interpretations of the legacy of Chinese philosophy. For the sake of brevity, the sole answer I will point to in this paper is that all of them identify the denotation 'Chinese' with their particular Legalist, Confucian or Daoist perspectives. Hence, they offer a 'total' interpretation of Chinese philosophy and China as such, which is overly narrow and yields a simplistic view of contemporary Chinese politics. As a result, it is necessary to emphasize a historical paradox, viz. that even after the great interest in Chinese Philosophy from some modern European philosophers (Zempliner, 1966; App, 2010; Roetz, 2013a), most of our knowledge about Chinese philosophy comes from sinologists or experts in cultural studies, rather than from political philosophers, who are capable of providing a more comprehensive view on such topics as politics, justice, legitimacy, authority, etc. ${ }^{7}$ This, in turn, sometimes leads to simplistic and mispresenting interpretations, which undermine an adequate representation of Chinese philosophy in the history of World philosophy, as well as its role in contemporary philosophical debates. ${ }^{8}$ In addition, it can hinder the adequate recognition of China as an autochthonous civilization with a distinctive perspective in relation to their 'path to modernity,' thereby undermining attempts to initiate an intercultural dialogue about human rights or towards the solution of problems connected with globalization.

From the above, we should draw the conclusion that we indeed have to avoid a form of Sino-romanticism and, therefore, stop speaking (and dreaming) about China as an ahistorical entity - as pointed out by Zádrapa in the introduction to his translation of Han Feizi. ${ }^{9}$ On the other hand, however, we should not look at China only negatively, as Zádrapa did. It is necessary to emphasize the fact that China and Chinese civilization is a multidimensional and complex entity with a very long history, which cannot be adequately described in comparatively simple terms of western social and political philosophy, which deals mostly with much smaller countries and homogenous societies. Consequently, the task for critical thinking is to work on Chinese philosophy - in all its complexities, i.e. philosophical schools, concepts, historical and present developments, and possible impacts on Western philosophy, as well as on contemporary Chinese society.

As the first step, which relates to the title of my paper, it is worth starting with an explanation of the word 'Confucianism' - as the most influential school of Chinese philosophy -, since for many Westerners this word evokes more a rigid state ideology, the ideology of adaptation (Roetz, 2006, p. 8) ${ }^{10}$ or a religion with some philosophical aspects,

\footnotetext{
${ }^{6} \mathrm{It}$ is one of the founding books of Confucianism.

${ }^{7}$ In relation to the Czech, Slovak and partially the German debate about Chinese philosophy, it is possible to claim that Chinese philosophy plays little or no role in mainstream philosophical debates. While the situation in the USA seems to be much better than in Europe, it is clear that there is still room for improvement: "Of the top 50 philosophy doctoral programs in the English-speaking world, only 15 percent have any regular faculty members who teach any non-Western philosophy" (Garfield \& Van Norden, 2016).

${ }^{8}$ More to this issue see in (Roetz, 1992, pp. 20-44).

9 "In traditional Sino-romantic China, featured by the timelessness and rigid immutability of oriental despotisms, are honourable philosophers presenting witty aphorisms. Zhuangzi's butterflies are flying around them while sipping tea in dusky teahouses, the landscape is painted with Chinese ink and poems are recited, which thanks to the character record "speak directly to eyes [translation - L.D., orig. in Czech]" (Zádrapa, 2011, p. 17).

${ }^{10}$ Roetz also criticizes Max Weber's (and Hegel's) interpretation of Confucianism (Roetz, 1992, p. 20).
} 
rather than designating a philosophical school, let alone a critical philosophy. It will be necessary, therefore, to explain the original meaning of the word Confucianism in order clear the ground for a new interpretation. I would argue that there is room for establishing a critical Confucian social theory, which is what Roetz and Stephen C. Angle essentially propose when they talk about 'Modern Confucianism' (Roetz, 2008a, pp. 376-379) or 'Progressive Confucianism' (Angle, 2012a) respectively.

The Chinese-American historian Hsu Cho-yun (X ǔ Zhuōyún) explains, that "although the English-language term 'Confucianism' is formed directly from the great sage's name, the original Chinese term, Ju-chia [Chinese: 儒家; pinyin: Rújia - L.D.], contains no reference to Confucius at all. The word 'Ju', as some historians have suggested, held two meanings. The first denoted experts of ritual, ceremony and archival materials - the scribes and diviners who rendered their services to the aristocracy. The second, a newer meaning, which I believe was consciously defined by Confucius, Mencius and other great Confucian scholars, denoted the carriers of the cultural heritage" (Hsu Cho-Yun, 2005, p. 457). Another possible translation of the Ru-jia doctrine is for instance the 'School of Literati,' as suggests Karyn Lai (Lai, 2008, p. 19). Roetz translates the word 'rújiā' as 'school of gentleness (meekness), or also 'school of the gentle'. He points out that "the school initiated by Confucius was not related to its founder, but to the mainly philological-intellectual and therefore peaceful activity of its adherents" [translation - L.D., orig. in German] (Roetz, 2006, p. 10). This means that supporters of that school were able to criticize even their master (Ibid., p. 15). Angle similarly stresses this critical potential, relying specifically on the Analects $18: 7,{ }^{11}$ as the basis for a progressive reading of Confucianism. Thus, he argues that "the classic Confucian texts provide little comfort for those who want to remain passive in the face of many imperfections of our world." On the other hand, he urges: "[S]till, a contemporary, Progressive Confucianism must offer clear guidance as to why and how a Confucian should engage in social critique today" (Angle, 2012a, p. 112).

From a contemporary perspective, Joseph Chan points out that the word 'Confucianism' like e.g. 'liberalism' "can be used at several levels: philosophical thought, political ideology, actual state policies and practices, or way of life. [...] Confucianism as a state ideology or practice was more a kind of product of time and historical circumstances, whereas Confucianism as a philosophical thought, founded by Confucius, has survived the test of time and remains today a lively source of ideas for the Chinese [similarly as other Chinese philosophical tradition, i.e. Daoism, Buddhism, Legalism, etc. - L.D.]. Moreover, separating the historical, institutional expression of a tradition of thought from its philosophical expression can create a space for people to critically evaluate, appropriate, and further develop that tradition of thought. Just as Marxists often turned to Marx's own words to denounce the political practices in communist states and develop new Marxian thinking on contemporary issues, we can likewise turn to the philosophical masters of Confucianism to do similar things" (Chan, 1999, p. 213).

To conclude the first part of this paper, although I am unable to substantiate the results of the inquiries of the aforementioned authors from a philological point of view, I find their arguments regarding the philosophical and undogmatic character of Confucian philosophy both convincing and inspiring for opening the path towards what we might call 'Critical Confucianism'.

\footnotetext{
11 "Not to serve is to have no sense of duty. Distinctions of age and youth may not be set aside; how can duties of ruler and subject be set aside? He wants to keep his person pure but as a result he disorders the great social relationships. The gentleman's serving is merely doing his duty. That the way does not obtain: this he know already" (Angle, 2012, p. 112).
} 


\section{Confucianism and Critical Theory}

It is possible to identify - at least at the official level - the ambitions of the Chinese government to develop China into "a prosperous, democratic, culturally advanced and harmonious modern socialist country" (Xi Jinping, 2014, p. 7), which at the same time does not lose its connection with its own traditions and cultural resources. ${ }^{12}$ As a matter of fact, the predominant Chinese interpretations of such terms like modernity, socialism, democracy, tradition etc. do not necessarily resonate with the most influential Western understandings of these terms. Nevertheless, our 'global situation' forces us to explore, which ideas and concepts from the cultural heritage of humankind are or might be suitable as principles of a global ethics.

The paper, however, attempts to present only some introductory ideas for initiating a discussion between a critical reading of the Confucian philosophical heritage and the tradition of Critical Social Theory, following Honneth's interpretation of the legacy of the Frankfurt School. The point of departure for this attempt is the conviction that emphasizing critical aspects of Confucianism, may help to contribute to the development of contemporary China as a truly modern, democratic and socialist country, not to mention the fact that Confucian philosophy is relevant for discussions about global ethics. At the same time, I believe a critical dialogue between the work of contemporary Chinese philosophers and those of critical theorists may help to develop (especially methodologically) the critical potential of Confucian philosophy. Conversely, such dialogue also has the potential to enrich Critical Theory, i.e. to contribute to its becoming a truly global theory. ${ }^{13}$

Although Roetz is in various ways critical towards the conservative reading of Confucianism (Roetz, 2008b; Roetz, 2013a) and towards the People's Republic of China in general (Roetz, 2011), he still regards Confucianism as relevant for a modern, postconventional ethics. According to Roetz: "Confucianism, provided it frees itself from its widespread traditionalistic self-misunderstanding, can even contribute to safeguarding the unitary (rather than multiple) 'project of modernity' as the normative, not merely technical and economic, project which it was in its early conceptualizations" (Roetz, 2008b, p. 376). As such, a productive confrontation with inspiring ideas from Confucianism and of other Chinese philosophical schools might help Critical Theory to become a real universal theory of modernity, not only an analysis of European modernity from a German perspective (Heubel, 2009, p. 65). On the other hand, Critical Theory might also be a natural 'ally' for Confucian thinkers, not only aiding them in their search for and in articulating their own critical resources, but also by opening new fields of research, which have hitherto been neglected (Heubel, 2009, p. 64).

By proposing a 'modern or left Confucianism,' Roetz emphasizes the dialectical relationship between self-regard (individual autonomy) and community: "such elements of

\footnotetext{
${ }^{12} \mathrm{Xi}$ Jinping's quotations, remarks and references show this awareness throughout his collected speeches.

${ }^{13}$ Jürgen Habermas, Axel Honneth and Rainer Forst, among the most prominent contemporary representatives of critical theory, would of course agree that in political and philosophical dialogue about global ethics and politics, all voices have to be heard impartially and with mutual respect and recognition. Comparative studies that would demonstrate such recognition - i.e. a serious interest to engage with and understand other cultures and civilizations - however, are unfortunately lacking in Critical Theory literature. There are indeed some attempts to open the tradition of critical theory to transcultural or global perspectives, e.g. Hans Herbert Kögler, Rainer Forst, Marek Hrubec, Melissa S. Williams and Mark E. Warren (Forst, 2014, pp. 241-266; Hrubec, 2010; Kögler, 2005; Williams \& Warren, 2014). Most of these works, however, emphasize the relevance of nonWestern cultures in a 'negative' sense in that they claim that the increase of global interactions is the main reason why we must discuss with these cultures. What is missing, therefore, is a 'positive' perspective, which would show the relevance of non-Western philosophies through a close analysis of their ideas from within their own traditions. This means, in short, that the aforementioned critical attempts have to be more 'concrete.'
} 
'second order,' 'detached' or 'post-conventional' thinking, that transcend the 'primordial' orientations and the 'embeddedness and rootedness of the human conditions' [...] without necessarily neglecting them, are the privileged points of departure to enter into a discourse with corresponding philosophies of other provenance like Western universalism (Roetz, 2008b, p. 378)." According to Roetz: "Confucians live in two worlds: the world of particular ethical duties with their detailed ritual prescriptions [...] and the world of the moral interest of the whole, which transcends the first world, relativizing and yet not negating it. This dialectic of Confucianism, on which its development potential otherwise depends, has all too often been overlooked by means of its prima facie conventional appearance" [translation - L.D., orig. in German] (Roetz, 2006, p. 22).

At this point in the comparison, I would like to stress the similar mediating and 'middle' position ${ }^{14}$ of Critical Theory between particular and universalistic perspectives with the aim of avoiding extremes of hegemonic oppression of a community or society, as well as of negative impacts of liberal selfishness. According to Honneth, the Hegelian idea of the rationality of cooperative self-actualisation is significant for a critical social theory and is critical towards both liberalism and communitarianism. He states - referring especially to Jürgen Habermas (but also to Marcuse, Horkheimer and Adorno) - that, "all the concepts of rational practice that find application in Critical Theory are tailored according to their intended use to actions whose implementation requires a higher degree of intersubjective agreement than liberalism allows. To be able to cooperate on an equal basis, to interact aesthetically, and to reach agreements in a non-coerced manner, a shared conviction is required that each of these activities is of an importance that justifies, if necessary, the neglect of individual interests" (Honneth, 2009, p. 27). On the other hand, as Honneth continues, "no critical theorist has ever abandoned the Hegelian idea that cooperative practice, along with the values attendant to it, must possess a rational character" (Honneth, 2009, p. 28). A transition to liberating practises of cooperation should not therefore result from an affective bond, or from a feeling of affiliation or approval, but rather from a rational perspective: ${ }^{15}$ "The tradition of Critical Theory thus differs from both liberalism and communitarianism by virtue of a particular kind of ethical perfectionism. [...] Unlike the liberal tradition, Critical Theory holds that the normative aim of society should consist in reciprocally making selfactualization possible. At the same time, it understands its recommendation of this aim to be the well-grounded result of a certain analysis of the human process of development" (Honneth, 2009, p. 28). ${ }^{16}$

One way of stimulating a fruitful dialogue between Critical Theory and Confucianism would be to appeal to Zhāng Dàinián's [张岱年] interpretation of a crucial ethical concept in Chinese philosophical tradition, viz. the concept of ren [仁], which is usually translated as 'humanity,' but could be also translated as 'care,' 'love,' or 'benevolence' (Zhang, Q., 2010, p. 54). The conclusion he draws from his historical reconstruction is of particular interest for our current purposes. According to Zhāng Dàinián, the adequate understanding of ren can be found in Dai Zhen's ${ }^{17}$ definition: "wanting to lead a fulfilling life oneself and also to bring

\footnotetext{
${ }^{14}$ The "middle position" of Confucianism is well-known and stressed by many authors. See for example the chapter 'Maß, Mitte und Harmonie' (Measure, Mean, and Harmony) (Roetz, 1992, pp. 173-180).

${ }^{15}$ To the understanding of rationality by Habermas and Honneth (Deranty, 2009, pp. 206-207).

16 Angle similarly speaks - following Joseph Chan - of 'moderate perfectionism': "some degree of state perfectionism is both necessary for a well-functioning state and society, and does not bring with it unacceptable costs. In particular, values like individual autonomy are not sacrificed, because moderate perfectionism endorses only widely shared values, does this in non-coercive ways, and contains independent for autonomy" (Angle, 2012, p. 140).

${ }^{17}$ Dai Zhen (Chinese: 戴震; 1724 - 1777) was a prominent Chinese scholar of the Qing dynasty.
} 
others to lead a fulfilling life is a straightforward and neat way of describing ren" (Zhang, D., 2005 , p. 310). ${ }^{18}$ While I recognize that providing an adequate definition of ren is a complicated task, ${ }^{19}$ I contend that it is at this very point that we can find a possible overlap. This is because the concept of ren suggests that a person (a social critic for instance), who wants to change and improve society (promote justice), must not understand the issue of a 'well-ordered society (or 'harmonious' in Confucian vocabulary)' in a narrow sense - e.g. merely in terms of legal principles or economical arrangements - but rather in a broader sense, viz. in terms of the (pre)conditions for a fulfilling life.

In order to highlight this connection, it is worth quoting from Honneth's analysis of the legacy of Critical Theory, which can serve as an appropriate point of departure for further discussion on the relationship between Confucianism and Critical Theory. "Critical Theory, [...] - in a way that may be unique to it - insists on a mediation of theory and history in a concept of socially effective rationality. That is, the historical past should be understood from a practical point of view: as a process of development [Bildungsprozess - in German original, which more directly emphasizes the importance of education - also for instance the Czech translation emphasizes stronger this aspect of this ambiguous word - L.D.] whose pathological deformation by capitalism may be overcome only by initiating a process of enlightenment among those involved" (Honneth, 2009, p. 21). "Even if it may be difficult to discover a systematic unity in the many forms of Critical Theory, taking the notion of the negativity of social theory as our point of departure will serve us well in establishing a first point of common interest. Not only the members of the inner circle but also those on the periphery of the Institute for Social Research perceive the societal situation on which they want to have an effect as being in a state of social negativity. Moreover, there is widespread agreement that the concept of negativity should not be restricted in a narrow way to offences committed against principles of social justice but, rather, should be extended more broadly to violations of the conditions for a good or successful life" (Honneth, 2009, p. 22).

While a more detailed analysis is beyond the scope of this paper, it is worth making two important remarks. First, the original German phrase 'ein gelingendes Leben,' is difficult to translate directly into English or even Chinese. While it has been translated as 'a successful life', a better rendering in this context would be "fulfilling", which in turn, manifests a closer relationship to the aforementioned interpretation of ren by Zhāng Dàinián. With regards to the Chinese translation, Fabian Heubel has preferred the term "guàntōng“貫通(for "gelingende Kommunikation") to chénggōng”成功. ${ }^{20}$ It is also worth noting important differences between various Czech translations. For example, the translator of Honneth's study 'Pathologies of the Social. The Past and Present of Social Philosophy' (Honneth, 2007, pp. 3-48) into Czech, Alena Bakešová, uses the word 'naplnený' (Honneth, 1996, p. 31), which could be translated as 'fulfilling'. However, in her translation of Honneth's book Pathologies of Reason. On the Legacy of Critical Theory she employs the word 'zdařily' (Honneth, 2011, p. 37), which might be translated as a combination of a 'successful' and 'fulfilling.' While there is clearly

\footnotetext{
${ }^{18}$ Dai Zhen [also] wrote: "In the life of human beings there is nothing worse than not being able to lead a fulfilling life. To lead a fulfilling life oneself and also to bring others to lead fulfilling lives is ren. To want to lead a fulfilling life oneself and not to care about the harm one does to others is a denial of ren. In truth, this denial of ren has its origin in the desire to lead a fulfilling life oneself. Suppose someone had no such desire anyway; then of course such a person would not be able to deny ren. But if one does not have the desire to lead a fulfilling life then one will not even look at the poorest and most desperate conditions of human life on the earth. On the other hand, there is no such desire as wanting others to lead a fulfilling life and not needing to lead a fulfilling life oneself"' (Zhang, D., 2005, p. 310).

${ }^{19}$ Compare for instance (Behr, 2015).

${ }^{20}$ As discussed at the $2015^{\prime}$ China-Workshop' titled, The Repressed Republic? China in the Light of its Revolutions, at the Institute of Social Research at the Goethe University in Frankfurt am Main.
} 
need for further discussion, I believe that for the purposes of this paper it is sufficient to indicate this important overlap between Critical Theory and Confucianism.

Second, it is important to emphasize that ren does not correspond to humanity in our 'Western,' Christian understanding, ${ }^{21}$ which generally refers to a positive attitude towards people. ${ }^{22}$ Indeed, "the character ren is composed of the graph for human being and that for the number two. It is expressive of the relations that should pertain among human beings" (Zhang, 2005, p. 285). However, it does not have to be understood only in positive terms or as referring exclusively to human behaviour towards other human beings. According to Marina Čarnogurská, it is not correct to understand the concepts of 'humanity' or 'justice' as a static ethical or moral "package of principles," as an attempt to construct ideal theories. As mentioned, the ideographical character ren is a picture of a human being and the number two. Thus, Čarnogurská argues that it is not adequate to translate it directly as humanity, but rather as an adequate contact and mutual interaction among human beings in a concrete society or in a concrete social sphere or situation. As a result, it neither means, for example, to act in every situation with compassion, nor does it mean to help or protect other people in every situation. In fact, "to provide ren" might sometimes mean - depending on the situation - that one has to be very hard on people and restrict their "rights.", 23

To return to Roetz, two additional commitments constitute the core of his reading of Confucian philosophy: "a priority of morals, which entails that one finds morally justifiable instead of merely technical, organizational or contractual solutions for all important questions of human existence, and that every human being, as a moral being (ens morale), has the potential to realize this priority in judgment and action-they can be brought in in order to safeguard and reformulate the foundations of a free modernity of solidarity" (Roetz, 2008b, pp. 378-379). The first commitment may be very important (and necessary - from my Central European perspective - especially for post-socialist countries, which are still not so successful at establishing the satisfactory level of the social foundations of democratic life), as well as in some narrow understandings - a problematic recommendation for contemporary political theory (in case of an overemphasizing of priority of moral). In fact, according to Angle, Confucianism, "long ago anticipated an important finding of contemporary psychology", viz. that "our social and physical environments have significant effects on the ways and degrees to

\footnotetext{
${ }^{21}$ As the example for unlimited love towards other, even bad, people see Jesus's suggestion from Matthew 5: "You have heard that it was said, '[an] Eye for eye, and [a] tooth for tooth.' But I tell you, do not resist an evil person. If anyone slaps you on the right cheek, turn to them the other cheek also. And if anyone wants to sue you and take your shirt, hand over your coat as well. ${ }^{41}$ If anyone forces you to go one mile, go with them two miles. Give to the one who asks you, and do not turn away from the one who wants to borrow from you (Matt5_3842)."

${ }^{22}$ According to Macmillan Dictionary the word humanity means: "a kind and sympathetic attitude towards other people, especially when they are suffering in some way" or "the state of being human, and of behaving and thinking in the same way as other people."

${ }^{23}$ Marina Čarnogurská-Ferancová applies this idea to understand the universe as a whole (ČarnogurskáFerancová, 2015; 2016) and argues - not unproblematically and uncontroversially but nevertheless inspiring that the Dao (another crucial concept of Chinese philosophy) is correspondingly non-anthropocentric and treats human beings as 'straw dogs' (Čarnogurská, 2009, p. 190). 'Straw dogs', i.e. figures of dogs made from cloth and stuffed with straw, were used in ancient China as the guardians of sacrificial places and sacrifices for deterring evil spirits. At the end of an offering or of the performance of their deterrent function, they would be destroyed. In the traditional Chinese world-view and especially in Daoism, objective reality was interpreted such that the 'Way of Dao' does not care for the existence of humankind and is governed by its own immanent regularities. If a human society or humanity as a whole wants to survive, then it must adapt to those regularities in order to avoid immanent catastrophic scenarios. Inability to cope with them means that the natural 'run' of Tao will deal with human beings as ruthlessly as with 'straw dogs'. Stahel' uses similar argumentation regarding rights restriction from environmental point of you (Stahel', 2016).
} 
which we can be virtuous [i.e. behaving or acting in a way that is morally good and right L.D.]. Confucian insights in this regard have been limited by their particularism, ${ }^{24}$ however, so Confucianism has sometimes been blind to the systematic effects of large-scale social and economic arrangements" [today especially formed and influenced by impacts of global capitalism - L.D.] (Angle, 2012a, 112). As a result, Angle argues that "Confucians must actively concern themselves with their socio-economic environments (Ibid.)" and this concern for establishing the proper social environment for developing a virtuous person - in which the moral behaving of those person support the well-functioning of institutions and so provide a well-ordered society - leads him to the conclusion that "many modern Confucians, finally have found socialism quite attractive" (Angle, 2012a, p. 135; Angle, 2012b).

To sum up, both Confucianism and Critical Theory appreciate the importance of community for self-creating individuals in finding themselves, their place in society through various forms of social recognition. Consequently, thinking about the kind of social preconditions for producing free, ethical and virtuous individuals (or collective and individual self-actualization)- as undertaken by Honneth in his recent works regarding the issue of democratic socialism (Honneth, 2014; 2015) can, in my view, provides a productive point of departure for a broad discussion between Confucianism and Critical Social Theory, one which promises to be productive for both philosophical traditions, as well as for contemporary debates in global ethics.

Lubomír Dunaj, is assistant professor at the University of Prešov (Institute of Political Sciences). He obtained an M.A. in History and Civics at the University of Prešov (2007) and a Ph.D. in Philosophy at the Comenius University in Bratislava. With the support of the German Academic Exchange Service (DAAD) and the National Scholarship Programme of the Slovak Republic, he spent time as a doctoral and post-doctoral research fellow at the Institute of Philosophy, Goethe University in Frankfurt am Main (2011, 2012, 2013-14). His areas of specialization are social and political philosophy and global studies and his current research focuses on the issue of justice and democracy under the conditions of globalization.

\section{Corresponding author:}

Lubomír Dunaj, Institute of Political Sciences, University of Prešov, 17 Novembra 1, SK08078 Prešov (Slovakia)

Email: lubomir.dunaj@unipo.sk

\section{References}

ANGLE, S. A. (2012a): Contemporary Confucian Political Philosophy: Toward Progressive Confucianism. Cambridge (UK) \& Malden (USA): Polity.

ANGLE, S. A. (2012b): Contemporary Confucian Perspectives on Social Justice. In: M. Palmer (ed.): Companion to Religion and Social Justice. New York, Blackwell, pp. 93-109. APP, U. (2010): The Birth of Orientalism. Philadelphia \& Oxford: University of Pennsylvania Press.

ARNASON, J. P., EISENSTADT, S. N. \& WITTROCK, B. (eds.) (2005): Axial Civilizations and World History. Leiden: Brill.

BEHR, W. (2015): Der gegenwärtige Forschungstand zur Etymologie von rén 仁 im Überblick. In: Bochumer Jahrbuch zur Ostasienforschung, 38, pp. 199-224.

\footnotetext{
${ }^{24}$ To this difficult issue see for instance (Roetz, 2008a)
} 
BELLAH, R. N. \& JOAS, H. (2012): The Axial Age and Its Consequences. Cambridge, MA \& London: The Belknap Press.

ČARNOGURSKÁ, M. (2009): Lao c' a proces vzniku Tao Te tingu, 1. diel [Laozi and the Process of the Genesis of Dao De jing, vol. 1]. Bratislava: Veda.

ČARNOGURSKÁ, M. (2012): Lao c' a proces vzniku Tao Te tíngu, 2. diel [Laozi and the Process of the Genesis of Dao De jing, vol. 2]. Bratislava: Veda.

ČARNOGURSKÁ-FERANCOVÁ, M. (2015): Modern World Needs Laozi's Wisdom about the Substance of Being and Living in Harmony with Nature. In: Sociology and Anthropology, 3(4), pp. 207-217.

ČARNOGURSKÁ-FERANCOVÁ, M. (2016): Modern Natural Sciences Could Inspire from Classical Chinese Metaphysics to Better Understand the Nature of Being. In: Universal Journal of Physics and Application, 10(5), pp. 157-169.

CCHAO SÜEČCHIN (2001-2006): Sen o Červenom pavilóne I.-IV. [A Dream of Red Mansions], trans. M. Čarnogurská. Bratislava: Petrus.

CHAN-FEJ-C' (2011): Vol. 1, trans. L. Zádrapa. Praha: Academia.

CHAN-FEJ-C' (2013): Vol. 2, trans. L. Zádrapa. Praha: Academia.

CHAN, J. (1999): A Confucian Perspective on Human Rights for Contemporary China. In: J. Bauer \& D. A. Bell (eds.): The East Asian Challenge for Human Rights. Cambridge: Cambridge University Press, pp. 212-237.

DERANTY, J.-P. (2009): Beyond Communication: A Critical Study of Axel Honneth's Social Philosophy. Leiden \& Boston: Brill.

FORST, R. (2014): The Right to Justification: Elements of a Constructivist Theory of Justice. New York: Columbia University Press.

GARFIELD, J. L. \& VAN NORDEN, B. W. (2016): If Philosophy Won't Diversify, Let's Call It What It Really Is. In: The New York Times. [Online] [Retrieved September 30, 2016] Available at: http://www.nytimes.com/2016/05/11/opinion/if-philosophy-wont-diversify-letscall-it-what-it-really-is.html?smprod=nytcore-ipad\&smid=nytcore-ipad-share\&_r=0

HEUBEL, F. (2009): Transkulturelle Kritik und die chinesische Moderne. Zwischen Frankfurter Schule und Neokonfuzianismus. In: I. Amelung \& A. Dippner (eds.): Kritische Verhältnisse. Die Rezeption der Frankfurter Schule in China. Frankfurt/New York: Campus Verlag, pp. 43-65.

HONNETH, A. (1996): Sociální filosofie a postmoderní etika. Praha: Filosofia.

HONNETH, A. (2007): Disrespect: The Normative Foundations of Critical Theory. Cambridge (UK) \& Malden (USA): Polity Press.

HONNETH, A. (2009): Pathologies of Reason: On the Legacy of Critical Theory. New York: Columbia University Press.

HONNETH, A. (2011): Patologie rozumu. Dějiny a současnost kritické teorie. Praha: Filosofia.

HONNETH, A. (2014): Freedom's Right: The Social Foundation of Democratic Life. Cambridge: Polity Press.

HONNETH, A. (2015): Die Idee des Sozialismus: Versuch einer Aktualisierung. Berlin: Suhrkamp.

HRUBEC, M. (2010): Preconditions of an Intercultural Dialogue on Human Rights. In: Veritas, 55(1), pp. 183-205.

HSU CHO-YUN (2005): Rethinking the Axial Age-The Case of Chinese Culture. In: J. P. Arnason, S. N. Eisenstadt \& B. Wittrock (eds.): Axial Civilizations and World History. Leiden: Brill, pp. 451-467.

KONFUCIUS (2002): Rozhovory a výroky (Lun Jü) [Analects of Confucius]. Bratislava: Slovenský Tatran. 
KWONG-LOI SHUN \& WONG, D. B. (eds.) (2004): Confucian Ethics: A Comparative Study of Self, Autonomy, and Community. Cambridge: Cambridge University Press.

KÖGLER, H.-H. (2005): Constructing a Cosmopolitan Public Sphere: Hermeneutic Capabilities and Universal Values. In: European Journal of Social Theory, 8(3), pp. 297-320.

LAI, K. (2008): An Introduction to Chinese Philosophy. New York: Cambridge University Press.

METZGER, T. A. (2005): A Cloud across the Pacific: Essays on the Clash between Chinese and Western Political Theories Today. Hong Kong: The Chinese University Press.

New Testament. Today's New International Version. Grand Rapids: Zondervan.

ROETZ, H. (1992): Die chinesische Ethik der Achsenzeit. Eine Rekonstruktion unter dem Aspekt des Durchbruchs zu postkonventionellem Denken. Frankfurt am Main: Suhrkamp.

ROETZ, H. (2006): Konfuzius. München: C.H. Beck.

ROETZ, H. (2008a): Confucianism and Familism: A Comment on the Debate between Liu and Guo. In: Dao: A Journal of Comparative Philosophy, 7(1), pp. 41-44.

ROETZ, H. (2008b): Confucianism between Tradition and Modernity, Religion, and Secularization: Questions to Tu Weiming. In: Dao: A Journal of Comparative Philosophy, 7(4), pp. 367-380.

ROETZ, H. (2011): Die Chinawissenschaften und die chinesischen Dissidenten. Wer betreibt die „Komplizenschaft mit der Macht"? In: Bochumer Jahrbuch zur Ostasienforschung, 35, pp. 47-79.

ROETZ, H. (2012): The Axial Age Theory: A Challenge to Historism or an Explanatory Device of Civilization Analysis? With a Look at the Normative Discourse in Axial Age China. In: R. N. Bellah \& H. Joas (eds): The Axial Age and Its Consequences. Cambridge, MA \& London: The Belknap Press, pp. 248-273.

ROETZ, H. (2013a): The Influence of Foreign Knowledge on Eighteenth Century European Secularism. In: M. Eggert \& L. Hölscher (eds.): Religion and Secularity: Transformations and Transfers of Religious Discourses in Europe and Asia. Leiden \& Boston: Brill, pp. 9-33. ROETZ, H. (2013b): A comment on Pragmatism in Chinese Studies. In: Confucianism in Inter-cultural Perspectives: Modern Developments. Paper from the Fourth International Conference on Sinology. Taipei: Academica Sinica, pp. 279-299.

SŤAHEL, R. (2016): Environmental Limits of Personal Freedom. In: Philosophica Critica 2(1), pp. 3-21.

VOCHALA, J. (2009): Konfucius v zrcadle sebraných výroki [Confucius in the Mirror of the Collected Sayings]. Praha: Academia.

WILLIAMS, M. S. \& WARREN, M. E. (2014): A Democratic Case for Comparative Political Theory. In: Political Theory, 42(1), pp. 26-57.

XI JINPING (2014): The Governance of China. Beijing: Foreign Languages Press.

YU, K. P., TAO, J. \& IVANHOE, P. J. (eds.) (2010): Taking Confucian Ethics Seriously. Albany: State University of New York Press.

ZÁDRAPA, L.: Předmluva [Introduction]. In: Chan-Fej-c', vol. 1, trans. L. Zádrapa. Praha: Academia, pp. 9-20.

ZEMPLINER, A. (1966): Čínská filosofie v novověké evropské filosofii [Chinese Philosophy in Modern European Philosophy]. Praha: Academia.

ZHANG, D. (2005): Key Concepts in Chinese Philosophy. Beijing, New Haven \& London: Foreign Languages Press and Yale University Press.

ZHANG, Q. (2010): Humanity or Benevolence? The Interpretation of Confucian Ren and its Modern Implications. In: K. P. Yu, J. Tao \& P. J. Ivanhoe (eds.): Taking Confucian Ethics Seriously. Albany: State University of New York Press, pp. 53-72. 